\title{
Insights into the Role of Bone Marrow-Derived Stem Cells in Renal Repair
}

\author{
Miriam Huls Frans G.M. Russel Rosalinde Masereeuw \\ Department of Pharmacology and Toxicology, Radboud University Nijmegen Medical Centre, Nijmegen Centre for \\ Molecular Life Sciences, Nijmegen, The Netherlands
}

\section{Key Words}

Acute renal injury $\cdot$ Ischemia-reperfusion - Renal function •

Remodeling $\cdot$ Bone marrow transplantation

\begin{abstract}
Acute kidney injury (AKI) is a frequent clinical problem with a high mortality rate, generally caused by ischemic insults. Nevertheless, the kidney has a remarkably high capacity to regenerate after ischemic injury. Tubular cells can restore renal function by proliferation and dedifferentiation into a mesenchymal cell type, but also stem cells residing in bone marrow may contribute. We compiled a protocol from several published methods to study the contribution of bone marrow-derived cells to renal regeneration. Bone marrow was isolated from donor FVB mice and labeled with enhanced green fluorescent protein (eGFP) through adenovirus transduction. After cell sorting, eGFP-labeled cells were transplanted in sublethally irradiated recipient FVB mice. Four weeks after transplantation, we provoked AKI in mice by inducing unilateral ischemic-reperfusion injury for 30 min. Seven days after the injury, eGFP-positive bone marrow-derived cells were clearly detectable in ischemic kidney tissue, and they contribute to the regeneration of approximately $10 \%$ of proximal tubular mass. In this review the advantages and shortcomings of our procedure are critically discussed and compared with other methods described.
\end{abstract}

Copyright $\odot 2008$ S. Karger AG, Basel

\section{Introduction}

Acute kidney injury (AKI) is defined as a rapid decrease in glomerular filtration rate (GFR) caused by both vascular and tubular factors, including increased renal vasoconstriction, loss of autoregulation and tubular obstruction $[1,2]$. Although incidence rates are decreasing, AKI is still associated with a high mortality rate. Nevertheless, the kidney has a remarkable regenerative capacity and is able to recover completely after renal failure. Ischemia reperfusion injury is the major cause of AKI, and after an ischemic event different processes are involved in the restoration of renal function. First, tubular epithelial cells have the ability to proliferate very rapidly and to migrate to the outer medulla where the majority of injury is observed [3]. Secondary to proliferation, tubular cells can dedifferentiate into a more mesenchymal cell type [4] and spread to the damaged area. In addition, bone marrow-derived stem cells may contribute to the regeneration of renal damage $[5,6]$.

Because stem cells have powerful self-renewing and tissue-regenerating properties they provide promising new therapeutic approaches for many unmet medical needs. Traditionally, stem cells were believed to be lineage-restricted and organ-specific. However, recent studies have demonstrated that bone marrow-derived hematopoietic stem cells are capable of forming functional components of other organ tissues, like skeletal muscle

\section{KARGER \\ Fax +41613061234 E-Mail karger@karger.ch} www.karger.com
Rosalinde Masereeuw, $\mathrm{PhD}$

Department of Pharmacology and Toxicology (149), Radboud University Nijmegen

Medical Centre, Nijmegen Centre for Molecular Life Sciences

PO Box 9101, NL-6500 HB Nijmegen (The Netherlands)

Tel. +31 243613 730, Fax +31 243614 214, E-Mail R.Masereeuw@ncmls.ru.nl 
Table 1. Comparison of technologies used to study renal regeneration after bone marrow transplantation

\begin{tabular}{|c|c|c|c|}
\hline Technology & $\begin{array}{l}\text { Isolation of bone marrow cells and } \\
\text { transplantation }\end{array}$ & Induction of renal ischemic injury & $\begin{array}{l}\text { Quantification of bone marrow-derived } \\
\text { stem cells in kidney repair }\end{array}$ \\
\hline $\begin{array}{l}\text { Specific } \\
\text { technologies }\end{array}$ & $\begin{array}{l}\text { 1. Labeling donor cells } \\
\text { 2. Irradiation techniques - lethal vs. sublethal } \\
\text { 3. Transplantation: } \\
\text { Full bone marrow vs. specific population }{ }^{\mathrm{a}} \\
\text { Time of transplantation }\end{array}$ & $\begin{array}{l}\text { 1. Operation procedure - flank vs. } \\
\text { midline incision } \\
\text { 2. Clamping time } \\
\text { 3. Time point ischemia induction }\end{array}$ & $\begin{array}{l}\text { 1. Immunohistochemistry } \\
\text { 2. Western blot analysis } \\
\text { 3. Functional analysis }\end{array}$ \\
\hline Pros & $\begin{array}{l}\text { 1. Detection bone marrow-derived cells } \\
\text { 2. No or limited influence of recipient bone } \\
\text { marrow cells } \\
\text { 3. Full bone marrow contains all (supporting) } \\
\text { cell populations }{ }^{\mathrm{a}} \text { - specific regenerative } \\
\text { capacities can be studied } \\
\text { Donor bone marrow cells can 'home' and } \\
\text { spread }\end{array}$ & $\begin{array}{l}\text { 1. Convenient methods of ischemia } \\
\text { induction; - flank incisions less harmful } \\
\text { for animal } \\
\text { 2. Controlled time leads to fixed degree of } \\
\text { damage } \\
\text { 3. Directly after transplantation is less } \\
\text { time-consuming }\end{array}$ & $\begin{array}{l}\text { 1. Direct overview of infiltrated cells in } \\
\text { the kidney } \\
\text { 2. Semiquantitative results of the } \\
\text { contribution of infiltrated cells } \\
\text { 3. Creatinine clearance and fractional } \\
\text { sodium excretion are relatively simple } \\
\text { and reliable tests }\end{array}$ \\
\hline Cons & $\begin{array}{l}\text { 1. eGFP sorting procedure causes a loss of cells } \\
\text { 2. Postoperative infections (lethal irradiation) - } \\
\text { Influence recipient bone marrow prevents } \\
\text { precise prediction of the stem cell regenerative } \\
\text { capacity (sublethal irradiation) } \\
\text { 3. Specific regenerative capacities are missed } \\
\text { Time-consuming experiments }^{\mathrm{b}}\end{array}$ & $\begin{array}{l}\text { 1. Midline incisions cause more often } \\
\text { postoperative infections } \\
\text { 2. Directly after transplantation causes } \\
\text { higher mortality }\end{array}$ & $\begin{array}{l}\text { 1. False positivity is seen; additional tests } \\
\text { are needed } \\
\text { 2. False positivity, perfusion of the } \\
\text { kidney is needed } \\
\text { 3. BUN values are not reliable; additional } \\
\text { tests need to be done }\end{array}$ \\
\hline References & $3,5,6,8,10$ & $3,5,10$ & $10,28,30$ \\
\hline
\end{tabular}

[7], heart [8], liver [9] and kidney [5, 6, 10]. In addition, after tissue injury, differentiation of hematopoietic stem cells into parenchymal cells seems to be stimulated, suggesting that these adult stem cells may also contribute to tissue repair. This review gives an overview of the techniques used in mice to study the role of bone marrow-derived stem cells in renal regeneration, which are summarized in table 1 . We critically compare our protocol developed for induction of acute ischemic kidney injury and full bone marrow cell transplantation with other published methods in order to gain more insight into renal regeneration by stem cells.

\section{Isolation of Bone Marrow Cells and Transplantation}

Freshly isolated bone marrow cells are used in all studies that investigate the regeneration potential of the stem cells they contain. We isolated full bone marrow by flushing the femurs and tibiae of the donor mice with medium or PBS. Bone marrow can also be isolated by mincing the bones in very small pieces followed by collagenase treatment [11]. This procedure is likely to be equally effective but is more time-consuming. The isolated cells can be transplanted directly, or cultured and labeled prior to transplantation $[3,5,11]$. In our study, isolated bone marrow cells were cultured and labeled with enhanced green fluorescent protein (eGFP). Upon culturing, it is a prerequisite that cells remain in the primitive stage, which can be achieved by addition of several specific growth factors, including thrombopoietin, stem cell factor and hematopoiesis blockers like transforming growth factor- $\beta$. To prevent host-versus-graft reaction, donor mice should be of the same strain to exclusively study the regenerative capacity of the bone marrow. After transplantation, donor bone marrow-derived cells have to be identified and discriminated from host cells. For that purpose, different labeling procedures have been described in the literature, the most effective of which are generation of chimeric mice (LacZ, eGFP, male/female mismatching) after transplantation.

Bone marrow transplantation can be performed with different cell populations. We used full bone marrow, but transplantations of the purified stem cell fraction, $\mathrm{Lin}^{-} \mathrm{Sca}-1^{+} \mathrm{c}-\mathrm{kit}^{+}$(KSL), have been described as well [5, 10]. The KSL markers are typical for a primitive population of cells in the bone marrow with a high reconstitution capacity $[12,13]$. The KSL fraction can be isolated 
using fluorescence-activated cell sorting analysis, by means of specific markers. To minimize the influence of the host bone marrow, recipient mice are irradiated either sublethally (3.5 Gy/animal) or lethally (11-12 Gy/animal [5]). Lethal irradiation of recipient animals increases the risk of (postoperative) infections, but minimizes the influence of endogenous bone marrow. As a result, a more reliable prediction of the influence of bone marrow cells in the regeneration processes is obtained. However, this may also be achieved after sublethal irradiation of the mice followed by transplantation of labeled bone marrow cells. In addition, high irradiation doses can cause tissue damage and promote cell fusion, which leads to falsepositive results [14]. After testing both methods, we preferred sublethal irradiation because of the improved health condition and survival rate of the animals. After irradiation, we transplanted 1 million eGFP-labeled bone marrow cells in recipient animals via tail vein injection, which is the most commonly used method. The quantity of transplanted cells varies between 200,000 and $5,000,000$ for full bone marrow and for a KSL fraction an amount of 20,000-30,000 cells is often used [5, 6, 10, 15, 16]. An advantage of KSL-selected cells is the specificity of this traditional bone marrow stem cell fraction. However, other stem cell fractions with a high differentiation potential, like multipotent adult progenitor cells $\left(\mathrm{Lin}^{-} \mathrm{Sca}-1^{\left.\text {low }_{C}-\mathrm{kit}^{-}\right)}\right.$[17], are excluded during KSL selection. A major advantage of using full bone marrow is that supporting cells are transplanted as well. This may contribute to a more stable population and, eventually, a more successful and reliable transplantation outcome.

\section{Induction of Renal Ischemic Injury to Study Bone Marrow-Derived Stem Cell Mobilization}

After a harmful insult, bone marrow-derived stem cells are mobilized to the damaged tissue where they differentiate into a specific phenotype for regeneration [5-8, 18]. Renal ischemia followed by reperfusion induces AKI, which triggers off the mobilization of bone marrow-derived stem cells. Nephrotoxicants like mercuric chloride $\left(\mathrm{HgCl}_{2}\right)$ [19], gentamicin or cisplatin [20-22] are occasionally used to study the role of bone marrow-derived stem cells in renal repair. We induced AKI by applying a clamp on the renal artery and vein for $30 \mathrm{~min}$. Prior to the induction of renal ischemic injury, mice were anesthetized with isoflurane and renal arteries and veins were exposed by an incision at the flank. Alternatively, a midline incision through the abdomen can be made. The ex- tent of ischemic damage is comparable for both methods; however, an abdominal incision increases the risk of complications. Moreover, postoperative pain medication can be minimized after a flank incision. The clamping time is variable and depends on the strain of mice used $[5,10]$. Depending on the extent of kidney injury, renal tubules regenerate with varying degrees of functional and structural recovery [23]. Histological examinations are required to confirm the degree of injury after ischemia. The ideal time point to induce renal ischemia after bone marrow transplantation is rather difficult to adjust. Ischemia can be induced directly after irradiation and transplantation $[5,10]$, but also after a longer period of time [3]. Inducing ischemia directly after transplantation and, consequently, also shortly after irradiation, is often associated with postoperative infections due to bone marrow deprivation [5]. Obviously, this limits the transplantation success. Moreover, after a longer time period it is expected that donor bone marrow cells move to the recipient bone marrow following spreading in the circulation. From that point of view, cells are able to react to ischemic signals and migrate to the site of injury, which might be less stressful for the transplanted cells although this has not been described. In our study, AKI was induced 4 weeks after bone marrow transplantation. Animal health improvement and survival rate were decisive for the protocol that was chosen eventually.

\section{Contribution of Bone Marrow-Derived Stem Cells to Renal Regeneration}

For quantification of the involvement of bone marrow-derived stem cells in renal tissue regeneration, different detection methods have been described. They are based on either cell labeling (e.g. with LacZ, eGFP) or gender mismatching [3]. These techniques have all been proven reliable, however, false-positive results were reported for gender mismatching caused by non-specific binding of probe aggregates $[3,10]$. For the cell labeling it should be noticed that positively stained cells are all derived from bone marrow but may not necessarily be labeled tubular cells. These false-positive results are most often caused by labeled leukocytes. This can, however, be prevented by performing a counterstaining of leukocytes with anti-CD45 antibodies or by antibodies directed against cell-specific markers, e.g. megalin for tubular cells. In addition, utilization of confocal microscopy in the analysis of bone marrow-derived cells is recommended. A confounder of eGFP detection may be a high auto- 

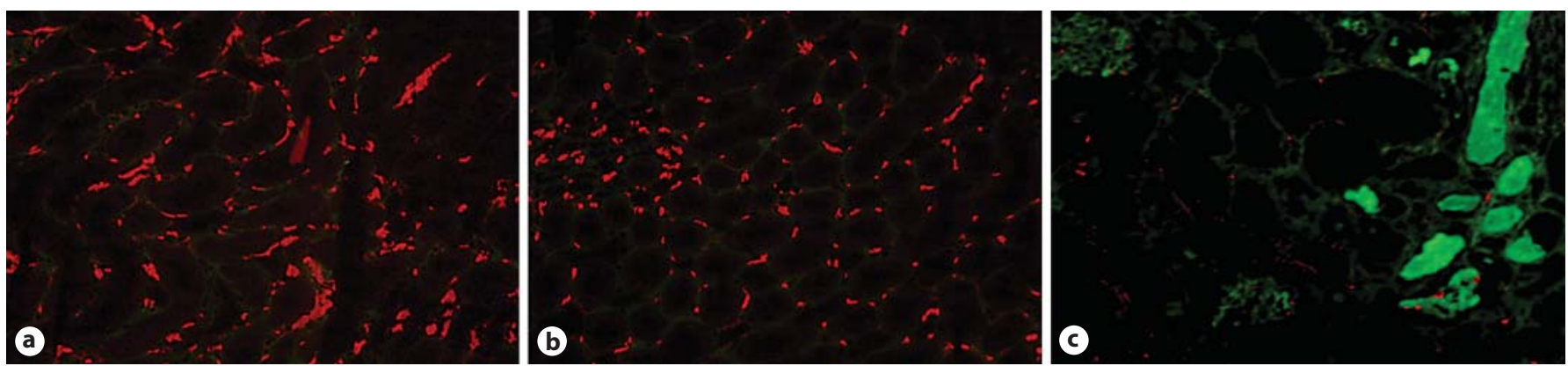

Fig. 1. Infiltration of eGFP-labeled bone marrow-derived cells in mouse kidney before (a), 2 days (b) and 7 days (c) after ischemia induction. $2-\mu \mathrm{m}$ cryostat sections were fixed in acetone for 10 min and air-dried. Subsequently, kidney slices were incubated with the primary antibodies against eGFP (Roche Diagnostics, Basel, Switzerland) diluted 1:200, or Ter-119/Ly-76 (Becton Dickinson, Breda, The Netherlands), a marker for erythrocytes, di-

luted 1:200. Next, slices were washed 3 times and incubated with the secondary antibody; goat anti-rabbit Alexa Fluo 488 was used for eGFP (green staining) or goat anti-rat Alexa Fluo 594 for Ter119/Ly-76 (red staining; both secondary antibodies obtained from Invitrogen, Breda, The Netherlands). Stained sections were examined using a confocal laser-scanning microscope (Leica Lasertechnik GmbH, Heidelberg, Germany). 200×.
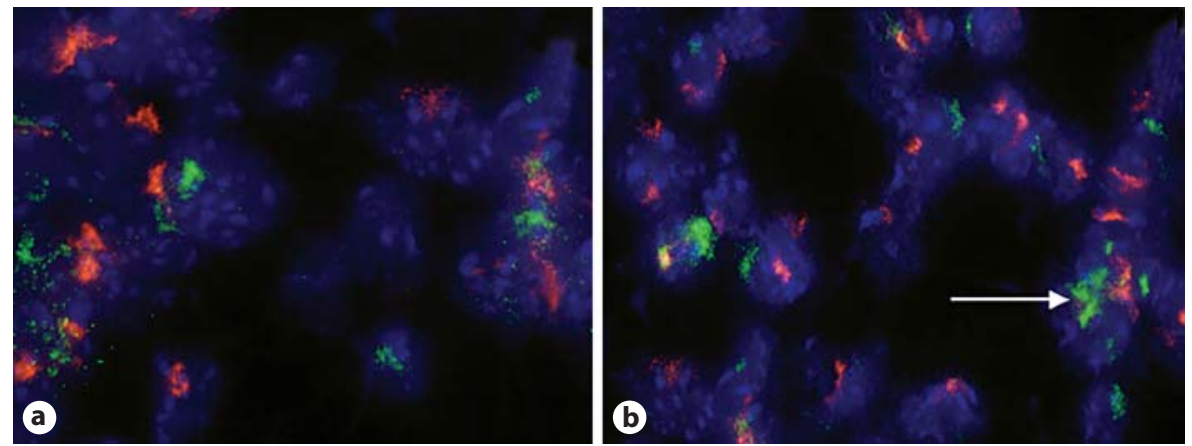

Fig. 2. Ischemic kidney injury recruits bone marrow-derived cells to renal tubules in gender-mismatched chimeras. After the transplantation of female bone marrow (XX) into male recipient (XY) mice, only XY cells were found and engraftment of female donor mice bone marrow cells in the recipient male kidney seems negligible 4 weeks after bone marrow transplantation before ischemic injury (a). However, 7 days postischemia, infiltration of XX-positive cells (indicated with arrow) in the male kidney was observed (b). Fluorescence in situ hybridization was performed using a mouse whole chromosome X paint (FITC, green) and Y (Cy3, red) (Cambio, Sanbio BV, Uden, The Netherlands). To this end, kidneys were perfused prior to isolation and snap-freezing in liquid nitrogen. $2-\mu \mathrm{m}$ cryostat sections were pretreated with pepsin (Sigma-Aldrich, Zwijndrecht, The Netherlands), prefixed in 70\% ethanol $-20^{\circ} \mathrm{C}$, washed with Nonidet P40 (Sigma) and dehydrat- ed. Of each chromosome paint, $3 \mu \mathrm{l}$ was used in a total of $10 \mu \mathrm{l}$ hybridization mix (Cambio) and administered under a coverslip of $20 \times 20 \mathrm{~mm}$ and denatured simultaneously on a Hybaid Omnislide (Thermo Electron, Breda, The Netherlands). Posthybridization was performed by a wash step of $0.4 \times$ SSC/Tween-20 at $68.5^{\circ} \mathrm{C}(1 \times \mathrm{SSC}$ is $0.15 \mathrm{M}$ sodium chloride $/ 0.015 \mathrm{M}$ sodium citrate) followed by several steps of $2 \times$ SSC, $4 \times$ SSC and PBS at room temperature. After dehydration the slides were hybridized with fluorescent probes to detect Y- and X-chromosomes, and counterstained with DAPI (blue) to show nuclei. A Zeiss Axiophot-2 microscope equipped with appropriate fluorescence filters was used for analysis of the fluorescence signals. Images were captured by Leica DC 350FX camera using a Leica CW4000 software package. $630 \times$. fluorescence of renal cells [24], therefore, the use of a primary antibody directed against GFP is recommended to raise the fluorescent signal above background levels.

After renal ischemic injury we observed that approximately $10 \%$ of the integral tubular segments orig- inated from transplanted bone marrow cells, which confirmed the results described in other publications $[5,10]$. Figure 1 is a representative image of the infiltration of eGFP-labeled bone marrow-derived cells 7 days after ischemia-reperfusion injury. This was confirmed in gen- 
der-mismatched chimeras in which bone marrow-derived cells were recruited to renal tubules (fig. 2). In accordance with Li et al. [25], fusion of stem cells with somatic cells does not account for the majority of the conversion of bone marrow cells to renal cells after ischemic injury. Western blot analysis can be used to quantify the amount of eGFP-positive bone marrow-derived cells in the kidney. A critical note, however, is that Western blot analysis can only differentiate between eGFP/ LacZ expression in tubular cells or in leukocytes when the kidney is perfused before isolation. Inflammatory processes often play a significant role in the pathophysiology of AKI causing, among others, outer medullary congestion [2]. Consequently, erythrocytes stick to the outer medulla, which hampers the perfusion procedure. In addition, attention should be paid to single tubularlike cells derived from the transplanted bone marrow, because these cells may also originate from donor leukocytes that fuse with residing tubular cells. To overcome these limitations, different identification techniques should be employed to confirm the findings.

Renal function tests are required to determine the outcome of the regeneration process. The most common functional parameters used are creatinine clearance and blood urea nitrogen (BUN) concentration $[5,26]$. Creatinine clearance is a widely accepted parameter for GFR assessment, although one should be cautious for misinterpretations caused by inadequate urine collection and differences in creatinine production. A decreased creatinine clearance accompanied by an unchanged serum creatinine concentration can be caused by inadequate urine collection. In addition, production of creatinine differs among and within individuals over time, depending on dietary intake (vegetarian diet, creatine supplements) or muscle mass. In this case, determinations of the renal clearance of inulin or other exogenous compounds, such as iothalamate, iohexol, or DTPA, are more reliable markers of GFR [27-29]. Individual variations in mice are, however, easy to exclude by using control animals which are genetically identical and are housed under the same conditions. Using our research protocol, a decreased creatinine clearance was observed 2 days after the induction of ischemia ( $p<0.001$ ), which returned to near normal levels on day 7 postischemia (data not shown).

The BUN concentration, on the other hand, is not as reliable as creatinine clearance, because it can vary independently of GFR changes due to variations in the rate of urea production. For example, a high protein diet results in an increase in BUN, as does enhanced tissue breakdown due to hemorrhage, trauma or corticosteroids.
Whenever BUN values are used to predict renal function, additional tests, like creatinine clearance or fractional sodium excretion, should be performed to get a more reliable assessment of renal function.

\section{Conclusions}

Considerable progress has been made in the development of different techniques to study the role of bone marrow-derived stem cells in ischemia-induced AKI. Using the method described in this review, we have shown that at least $10 \%$ of the regenerated proximal tubular segments originate from donor bone marrow. However, controversial results have been reported in the literature, mainly originating from differences in experimental models. We have listed the currently available techniques in table 1 to aid in the selection of the most appropriate experimental model. Bone marrow consists of several stem cell populations and the specific types responsible for regeneration of damaged kidney tissue are still not known. It is likely that more subpopulations are responsible for this process, but their contribution has yet to be investigated by transplantation of the purified fractions.

To study the regeneration process in vivo, mice should be in a good health condition to prevent the influence of other confounding factors. To achieve this, AKI should not be induced sooner than a few weeks after transplantation. In addition to a better physical condition of the recipient mice, a longer period between transplantation and injury induction is also beneficial for the regeneration process. Moreover, a longer time period allows cells to spread and migrate in the circulation, and to reconstitute the bone marrow.

Finally, to assess the overall contribution of bone marrow-derived stem cells in kidney regeneration, several methods can be applied, of which immunohistochemistry is the most reliable technique. An important issue is the exclusion of false-positive cells. The use of confocal microscopy and (double) staining of the kidney samples in quantitative analysis and the gender-mismatching procedure in donor and recipient mice reduces the chance of false-positive results. The outcome of kidney renewal after acute injury can be investigated by several functional tests. Although these tests do not cover the contribution of bone marrow cells, they give detailed information about the progression of the regeneration process and help in the comparison of different protocols.

The use of appropriate in vivo models accompanied with more in vitro data about the differentiation process 
from stem cell into renal cell, will provide research tools to obtain more mechanistic insight in the regeneration process. Yet, the development of an in vitro assay, in which cultured renal cells differentiate from primitive stem cells, is still a major challenge. Within the bone marrow, several stem cell populations have pluripotent characteristics. Transplantations with the hematopoietic stem cell population or mesenchymal stem cell population did not improve the renal repair process, but a third cell population, the multipotent adult progenitor cells, may still be promising [17]. This cell type might have the capacity to differentiate in vitro towards renal cells, and eventually could provide a valuable source of cells for transplantation and therapy. However, the kidney consists of a very heterogeneous cell population. At this moment an in vitro assay cannot imitate the complexity of kidney development in vivo, which limits the use of cultured renal cells for our research questions. The transplantation of bone marrow-derived stem cells in vivo is, however, promising and opens new possibilities for cellular therapies of renal disease. Autologous transplantation of stem cells may evidently minimize the use of donor organs and immunosuppressants, and possibly maximizes the success of tissue remodeling. Obviously, this is a next challenge to regeneration science.

\section{Acknowledgements}

Miriam Huls was supported by a grant from the Dutch Kidney Foundation (C02.2012). The authors thank Gerard F.M. Merkx for his technical support in the fluorescence in situ hybridization experiments.

\section{References}

1 Kribben A, Edelstein CL, Schrier RW: Pathophysiology of acute renal failure. J Nephrol 1999;12(suppl 2):S142-S151

-2 Schrier RW, Wang W, Poole B, Mitra A: Acute renal failure: definitions, diagnosis, pathogenesis, and therapy. J Clin Invest 2004;114:5-14.

3 Duffield JS, Bonventre JV: Kidney tubular epithelium is restored without replacement with bone marrow-derived cells during repair after ischemic injury. Kidney Int 2005; 68:1956-1961.

4 Witzgall R, Brown D, Schwarz C, Bonventre JV: Localization of proliferating cell nuclear antigen, vimentin, c-Fos, and clusterin in the postischemic kidney. Evidence for a heterogenous genetic response among nephron segments, and a large pool of mitotically active and dedifferentiated cells. J Clin Invest 1994; 93:2175-2188.

5 Kale S, Karihaloo A, Clark PR, Kashgarian M, Krause DS, Cantley LG: Bone marrow stem cells contribute to repair of the ischemically injured renal tubule. J Clin Invest 2003;112:42-49.

- 6 Poulsom R, Forbes SJ, Hodivala-Dilke K, Ryan E, Wyles S, Navaratnarasah S, Jeffery $\mathrm{R}$, Hunt $\mathrm{T}$, Alison $\mathrm{M}$, Cook T, Pusey C, Wright NA: Bone marrow contributes to renal parenchymal turnover and regeneration. J Pathol 2001;195:229-235.

7 Ferrari G, Cusella-De Angelis G, Coletta M, Paolucci E, Stornaiuolo A, Cossu G, Mavilio F: Muscle regeneration by bone marrow-derived myogenic progenitors. Science 1998; 279:1528-1530.
8 Orlic D, Kajstura J, Chimenti S, Bodine DM, Leri A, Anversa P: Transplanted adult bone marrow cells repair myocardial infarcts in mice. Ann NY Acad Sci 2001;938:221-229.

$\checkmark 9$ Lagasse E, Connors H, Al Dhalimy M, Reitsma M, Dohse M, Osborne L, Wang X, Finegold M, Weissman IL, Grompe M: Purified hematopoietic stem cells can differentiate into hepatocytes in vivo. Nat Med 2000; 6:1229-1234.

10 Lin F, Cordes K, Li L, Hood L, Couser WG, Shankland SJ, Igarashi P: Hematopoietic stem cells contribute to the regeneration of renal tubules after renal ischemia-reperfusion injury in mice. J Am Soc Nephrol 2003; 14:1188-1199.

-11 Breyer A, Estharabadi N, Oki M, Ulloa F, Nelson-Holte M, Lien L, Jiang Y: Multipotent adult progenitor cell isolation and culture procedures. Exp Hematol 2006;34:15961601.

12 Zhou S, Schuetz JD, Bunting KD, Colapietro AM, Sampath J, Morris JJ, Lagutina I, Grosveld GC, Osawa M, Nakauchi $H$, Sorrentino $\mathrm{BP}$ : The $\mathrm{ABC}$ transporter Bcrp1/ABCG2 is expressed in a wide variety of stem cells and is a molecular determinant of the side-population phenotype. Nat Med 2001;7:10281034.

13 Osawa M, Hanada K, Hamada H, Nakauchi $\mathrm{H}$ : Long-term lymphohematopoietic reconstitution by a single CD34-low/negative hematopoietic stem cell. Science 1996;273:242245.

14 Harris RG, Herzog EL, Bruscia EM, Grove JE, Van Arnam JS, Krause DS: Lack of a fusion requirement for development of bone marrow-derived epithelia. Science 2004;305: 90-93.
5 Morigi M, Imberti B, Zoja C, Corna D, Tomasoni S, Abbate M, Rottoli D, Angioletti S, Benigni A, Perico N, Alison M, Remuzzi G: Mesenchymal stem cells are renotropic, helping to repair the kidney and improve function in acute renal failure. J Am Soc Nephrol 2004;15:1794-1804.

16 Dekel B, Zangi L, Shezen E, Reich-Zeliger S, Eventov-Friedman S, Katchman H, JacobHirsch J, Amariglio N, Rechavi G, Margalit $\mathrm{R}$, Reisner Y: Isolation and characterization of nontubular sca- $1^{+} \mathrm{lin}^{-}$multipotent stem/ progenitor cells from adult mouse kidney. J Am Soc Nephrol 2006;17:3300-3314.

17 Jiang Y, Jahagirdar BN, Reinhardt RL, Schwartz RE, Keene CD, Ortiz-Gonzalez XR, Reyes M, Lenvik T, Lund T, Blackstad M, Du J, Aldrich S, Lisberg A, Low WC, Largaespada DA, Verfaillie CM: Pluripotency of mesenchymal stem cells derived from adult marrow. Nature 2002;418:41-49.

18 Krause DS, Theise ND, Collector MI, Henegariu O, Hwang S, Gardner R, Neutzel S, Sharkis SJ: Multi-organ, multi-lineage engraftment by a single bone marrow-derived stem cell. Cell 2001;105:369-377.

19 Horikawa S, Ito K, Ikeda S, Shibata T, Ishizuka S, Yano T, Hagiwara K, Ozasa H, Katsuyama I: Induction of heme oxygenase-1 in toxic renal injury: mercuric chloride-induced acute renal failure in rat. Toxicol Lett 1998;94:57-64.

20 Cuzzocrea S, Mazzon E, Dugo L, Serraino I, Di Paola R, Britti D, De Sarro A, Pierpaoli S, Caputi A, Masini E, Salvemini D: A role for superoxide in gentamicin-mediated nephropathy in rats. Eur J Pharmacol 2002;450: 67-76. 
-21 Al Majed AA, Mostafa AM, Al Rikabi AC, Al Shabanah OA: Protective effects of oral arabic gum administration on gentamicin-induced nephrotoxicity in rats. Pharmacol Res 2002;46:445-451.

-22 Cvitkovic E: Cumulative toxicities from cisplatin therapy and current cytoprotective measures. Cancer Treat Rev 1998;24:265281.

-23 Ysebaert DK, De Greef KE, Vercauteren SR, Ghielli M, Verpooten GA, Eyskens EJ, De Broe ME: Identification and kinetics of leukocytes after severe ischaemia/reperfusion renal injury. Nephrol Dial Transplant 2000; 15:1562-1574.
24 Jackson KA, Snyder DS, Goodell MA: Skeletal muscle fiber-specific green autofluorescence: potential for stem cell engraftment artifacts. Stem Cells 2004;22:180-187.

25 Li L, Truong P, Igarashi P, Lin F: Renal and bone marrow cells fuse after renal ischemic injury. J Am Soc Nephrol 2007;18:30673077.

26 Zerbini G, Piemonti L, Maestroni A, Dell'Antonio G, Bianchi G: Stem cells and the kidney: a new therapeutic tool? J Am Soc Nephrol 2006;17:S123-S126.

27 Rahn KH, Heidenreich S, Bruckner D: How to assess glomerular function and damage in humans. J Hypertens 1999;17:309-317.
28 Levey AS: Measurement of renal function in chronic renal disease. Kidney Int 1990;38: 167-184.

-29 Brandstrom E, Grzegorczyk A, Jacobsson L, Friberg P, Lindahl A, Aurell M: GFR measurement with iohexol and ${ }^{51} \mathrm{Cr}$-EDTA. A comparison of the two favoured GFR markers in Europe. Nephrol Dial Transplant 1998; 13:1176-1182.

30 Van Acker BA, Koomen GC, Koopman MG, de Waart DR, Arisz L: Creatinine clearance during cimetidine administration for measurement of glomerular filtration rate. Lancet 1992;340:1326-1329. 